\title{
Economic benefits or drivers of a 'One Health' approach: Why should anyone invest?
}

\begin{abstract}
Authors:
Jonathan Rushton ${ }^{1}$ Barbara Häsler ${ }^{2}$ Nicoline de $\mathrm{Haan}^{3}$ Ruth Rushton ${ }^{4}$

\section{Affiliations:}

${ }^{1}$ Animal Health Economics, RVC, United Kingdom

${ }^{2}$ Agrihealth, RVC and LCIRAH, United Kingdom

${ }^{3}$ Food and Agriculture Organisation of the United Nations, Rome, Italy

${ }^{4}$ Forensic Psychologist, Independent Consultant, United Kingdom

Correspondence to: Jonathan Rushton

Email:

jrushton@rvc.ac.uk

\section{Postal address:}

Royal Veterinary College,

Hawkshead Lane, North

Mymms, Hatfield, Herts,

AL9 7TA

How to cite this proceeding: Rushton, J., Häsler, B., De Haan, N. \& Rushton, R., 2012, 'Economic benefits or drivers of a "One Health" approach: Why should anyone invest?', Onderstepoort Journal of Veterinary Research 79(2), Art. \#461, 5 pages. http:// dx.doi.org/10.4102/ojvr. v79i2.461

Note:

Proceedings of the Conference of the Southern African Centre for Infectious Disease Surveillance 'One Health' held at the National Institute for Communicable Diseases, Johannesburg, July 2011.
\end{abstract}

C 2012. The Authors Licensee: AOSIS OpenJournals. This work is licensed under the Creative Commons Attribution License.
One Health concepts and ideas are some of the oldest in the health discipline, yet they have not become main stream. Recent discussions of the need for One Health approaches require some reflection on how to present a case for greater investments. The paper approaches this problem from the perspective of the control and management of resources for health in general. It poses the following questions, (1) where do we need extra resources for One Health, (2) where can we save resources through a One Health approach and (3) who has control of the resources that do exist for One Health? In answering these questions three broad areas are explored, (1) The management and resources allocated for diseases, (2) The isolation of parts of the society that require human and animal health services and (3) The use of resources and skills that are easily transferable between human and animal health.

The paper concludes that One Health approaches are applicable in many scenarios. However, the costs of getting people from different disciplines to work together in order to achieve a true One Health approach can be large. To generate tangible benefits requires careful management of specialist skills, knowledge and equipment, which can only be achieved by a greater openness of the human and animal health disciplines. Without this openness, policy makers will continue to doubt the real value of One Health. In summary the future success of One Health is about people working in the research, education and provision of health systems around the world embracing and managing change more effectively.

\section{Introduction}

Since 2008 a number meetings have taken place and documents produced (Food and Agriculture Organisation/World Animal Health Organisation/World Health Organisation 2008; Chatham House 2010; Canadian Public Health Agency 2009; World Bank 2010) that have raised the need for a more holistic approach to problems that affect the health of humans, animals and the general environment. Such an approach is not new, but the need for it has been given a much sharper focus with the increasing incidence of diseases that have the potential of creating large economic impacts, human deaths and losses of environmental diversity.

The articulation of the need to adopt a One Health approach was accepted at a meeting of governments (IMCAPI) in Hanoi in April 2010. This was followed by a meeting in Stone Mountain, Georgia, USA to discuss how One Health can be operationalised. One of the recommendations of that meeting was the need for a document that clearly presents an investment strategy for One Health. Whilst the authors acknowledge the ongoing work in this area, the general feeling is that the One Health approach is still some way from being main stream with human and animal health policy making. The questions that come to mind are:

- Why is One Health not main stream?

- If One Health is important, how can the case for a major paradigm shift be more persuasively presented?

The paper explores these questions from the perspective of resource allocation namely by looking at, (1) where extra resources are needed for One Health, (2) where resources can be saved with a One Health approach, and (3) who has control of the resources that do exist for One Health at the moment.

\section{Background}

The environments generating health problems are dynamic. The human population continues to grow with expansions greatest in the last fifty years occurring in the developing world (Figure 1).

In addition to the growth in populations there are constant changes in the movement of people and settlement patterns. Some the most dramatic have been the movements of people from Central America and Mexico to North America in the last 15 years and in general the 
movement of people to urban environments. To keep pace with these changes livestock systems and their associated value chains have evolved. Delgado et al. (1999) described this as a livestock revolution; in fact it was a second revolution, as the first occurred in the 1800s in Europe and the associated colonies (Rushton 2009). This first revolution was largely based on ruminant production, and the second and most recent revolution being based largely on intensive monogastric systems and to some extent from a growth in milk production. The world has seen greater specialisation and intensification of livestock systems leading to increased output per animal and per unit of labour. There has also been massive expansion of livestock populations particularly poultry and pigs and a concentration and clustering of livestock populations. In general there has been an increase in the sophistication and globalisation of livestock product value chains.

Originally these changes in the livestock sector were celebrated although there were early concerns of poorer livestock producers being left behind (De Haan et al. 2001; Heffernan 2002; Food and Agriculture Organisation 2005; Owen et al. 2005) and negative impacts on the environment (De Haan, Steinfeld \& Blackburn 1997; Steinfeld et al. 2006).

What was not anticipated were the growing problems with the control of transboundary animal diseases and more specifically the resurgence of zoonotic diseases (Greger 2007). One of the issues that has been raised it is that as domestic livestock populations increase there has been greater contact with wildlife. Also as human populations have pushed into new areas there has been increased contact between human populations and wildlife. Therefore potentially two different sources of diseases either through direct contact with wild animals or through domestic species possible acting as liaison hosts. In addition to these contacts with wildlife the emerging food chains have generated greater levels of moral hazard (asymmetry of information) where people consuming livestock products are unlikely to know how animals are raised and fed, and how the product was handled and stored before it arrives on the plate. An extreme example of this comes from the UK where only 339000 people work in agricultural holdings (only $0.6 \%$ of the population) yet they produce food and therefore can affect the wellbeing of 60 million people (see Figure 2).

Responses to these existing and emerging challenges have been strong with greater control of many transboundary animal diseases, and success stores such as the global eradication of rinderpest and the regional eradication of diseases such as foot and mouth disease and classical swine fever. However, there have been major setbacks such as bovine spongiform encephalopathy, SARs and highly pathogenic avian influenza H5N1. The emergence of these problems and the apparent increase in the frequency at which such pathogens emerge (Woolhouse \& Gowtage-Sequeria 2005; Woolhouse 2008; Jones et al. 2009) indicate a need to reassess how the world deals with change and manages health. As the livestock sector and human society changes there is a need to monitor with different intensities and manage

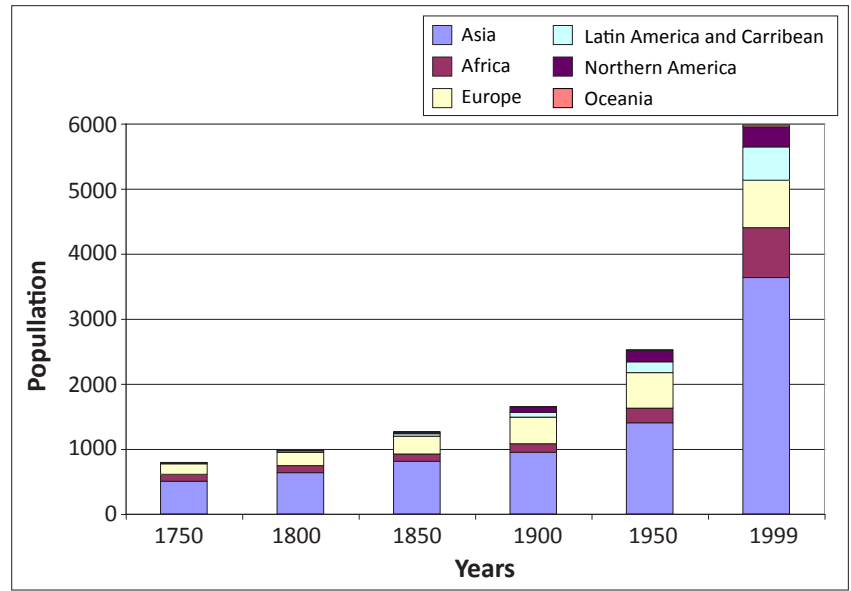

Source: United Nations cited on http://www.statistics.gov.uk/StatBase/

FIGURE 1: World Population from 1850 to 1999.

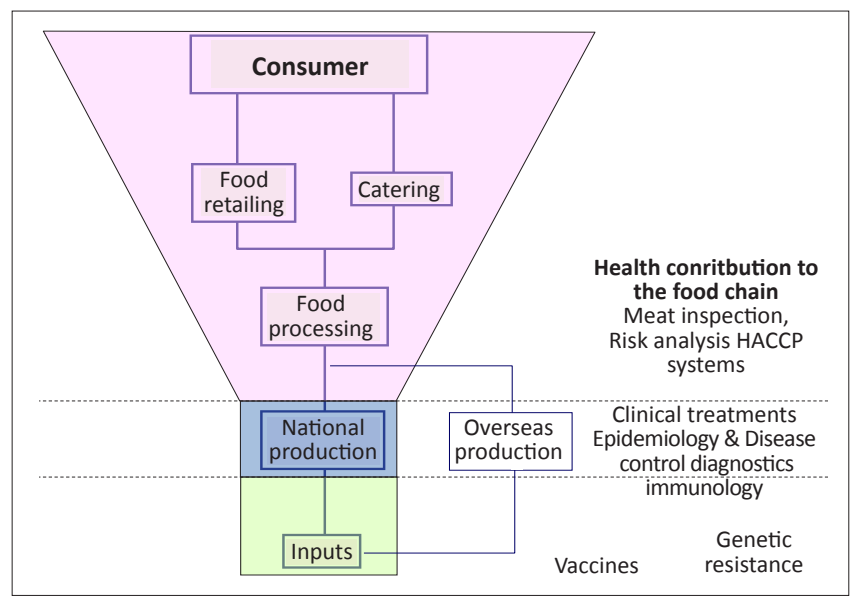

FIGURE 2: Health contributions to the food chain.

health risks in different ways. Where risks can be quantified there has been a tendency towards allocating resources for monitoring and management in a targeted manner. Yet the predictions of the emergence and re-emergence of disease problems have not been strong with obvious examples being BSE, H5N1, H1N1. There are two possibilities from this scenario: what we are observing are not predictable events they are random and cannot be identified through commonly used statistical methods or that our current risk models are inadequate at simulating reality. Either could be true, the more immediate challenge is to redirect resources so that problems as they emerge are addressed proportionately to the impact they cause and that response are not based on fears that are held. To achieve this there is a need for information on how resources are currently allocated and whether this use of use resources could be improved.

\section{Economic logic for investment in One Health}

Investments in One Health need to recognise two different aspects:

- Disease impact

- Costs of disease in terms of losses in production of livestock

- Costs of controlling the disease

- Human health impacts and costs 
- Avoidable losses - the costs of disease that can be avoided by implementing a disease control programme.

The disease impact gives some idea of the economic importance of a problem and whether there is a need to dedicate further resources in terms of education and research. The decision on surveillance and intervention needs to assess if their costs are less than the avoidable losses generated. The following sections will explore areas in One Health where this could be the case.

\section{Looking at resources in the health system}

The section is divided into three different areas, (1) resources dedicated to specific disease problems across humans and animals, (2) human populations that have poor access to resources for health and (3) resources can be moved between human and animal health issues easily.

\section{Responses to specific diseases and health problems}

Diseases can be relatively easily split into those that are problematic in humans, those that are problematic in animals and those can cause problems in both human and animal populations. The authors would suggest that the most appropriate approaches to diseases that cause problems in humans or animal populations need specialised approaches and in general this is how human health and animal health systems have evolved. However, the diseases that cause problems in both humans and animals - the zoonoses require generalised approaches (Figure 3).

Some of the zoonotic diseases cause significant impacts in specific locations (Knobel et al. 2005 for rabies), and some that are classified as zoonotic cause huge disruptions (Otte et al. 2010 for HPAI H5N1). However, the zoonotic diseases as a whole do not tend to have a large enough impact in human and animal populations at the same time to have warranted the creation of generalised health service that approaches the problems from a combined human and animal population perspective (Maudlin, Eisler \& Welburn 2009). For example, tuberculosis is one of world's major human disease problems, but the causative and self maintaining pathogen of this disease is not Mycobacterium bovis, the pathogen in cattle, it is Mycobacterium tuberculosis. Therefore whilst the disease complex as a whole could be considered zoonotic,

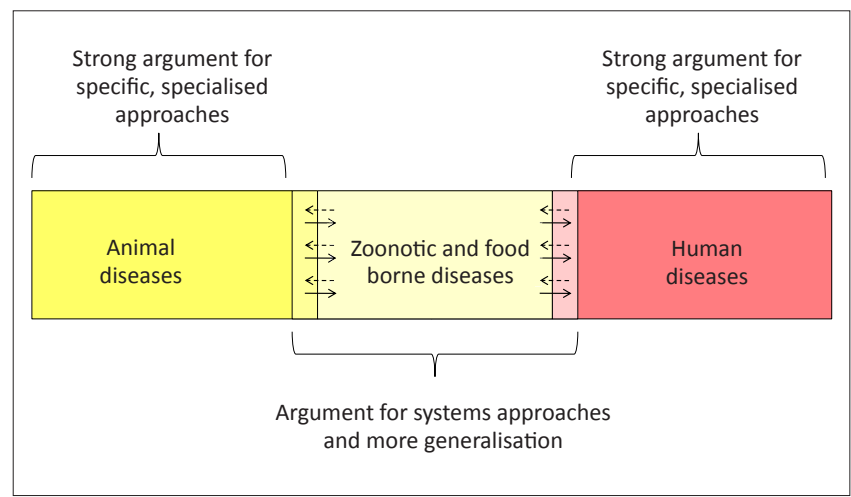

FIGURE 3: Disease groupings and the appropriate responses. the pathogens tend to be species specific with some spillover into other species populations. Similarly, brucellosis pathogens are specific to livestock species with spillover into humans where the pathogen can remain but not spread between people. Probably the most challenging pathogens in terms of affecting both human and animal populations are the parasitic problems such as cysticercosis and cystic echinococcosis.

This is not to argue that zoonotic diseases are not important, but that as a group they do not seem to cause sufficient impact across both human and animal populations for societies to have a cadre of people who work across species or organisations that follow the disease across animal and human populations. The problem actually lies in where resources are spent on diseases that circulate in animals and cause spillover impacts in the human population. For example brucellosis causes a significant economic impact, but the costs of controlling the disease in animals are greater than the benefits generated in the animal population, it is only when benefits from the prevention of disease in humans is taken into account that the costs are exceeded (Roth $e t$ al. 2003). The implications for such disease problems is the need for One Health thinking at a much higher level of budgetary and resource allocation, so that control campaigns in animals are sufficiently well financed to lead to benefits in humans. This requires a proactive and preventative approach to disease management, a recognition that disease can be managed further upstream, which requires significant shifts in resource allocation. It does not necessarily mean closer working mechanisms in the field.

There are examples where there has been a need and a successful implementation of One Health in the eradication of disease with strong field level coordination such as the control of cystic echinococcosis and Echinococcus in places such as New Zealand and the ongoing attempts to remove cysticercosis from the northern area of Peru (Gonzalez 2011).

It is also argued that the non-communicable diseases is a problem that deserves more thought on how best to harness One Health approaches. Food chains process and refine food for both animals and humans and this has important implications on food intake nutritional health and resulting diseases. These aspects are rarely treated as One Health issues and are invariably observed and worried about rather than thinking of the underlying causes. They would require a more general rather than disease specific approach.

In common with all the disease groups there is the need for an understanding of the role of human behaviour in terms bringing host and pathogen together. There is also a need to understand and use how we react when a disease is present which could be in a positive manner in terms of controlling disease and also in negative manner leading to the maintenance of disease. The latter could be due to ignorance and/or economic gain. Finally human behaviour plays a role in consumption and therefore the emergence of non-communicable diseases. 
To attract and retain resources that are applied to specialised activities in terms of dealing with diseases there would be a need for an agreement of the human and animal health leaders on who leads, who implements and who gets the resources. In some cases there will be strong arguments that integrated field level approaches are not necessary, but that these require One Health thinking at a budgetary allocation point. Other diseases do require much more integrated approaches such as specific parasitic diseases and the noncommunicable diseases.

\section{Where resources are scarce}

Many people live in geographical isolation in areas where they are reliant on livestock. Making resources available in these areas for either human or animal health is difficult due to the limited availability of trained resources and the lack of demand for such services. The need for One Health approaches would make sense in terms of matching overall demand for animal and human health services and the potential to supply adequate services. Strong arguments for generalised services and these have been well documented (Schelling et al. 2007; Zinsstag et al. 2007).

Some lessons from these generalised approaches would benefit from examining the literature on the integrated rural development programmes (Roling \& Wagemarkers 1998; Morton, Matthewmaan \& Barton 1997; Van Veldhuizen et al. 1997). Indeed, One Health services probably need to incorporate aspects of animal production and genetics, water and sanitation and potentially plant health in such regions.

\section{Where resources are underutilised}

Many human health and animal health facilities are built that replicate capacity and in some cases have relatively low throughput. In addition there is human capacity building in data collection, storage and analysis skills in the two health areas. In the case of human capacity this can often be in too few numbers and/or with a low demand of their skills in their specific health field

Low throughput and low demand often leads to poor calibration of standards and variable output of results. Small numbers of trained people limit interchange and advancement in knowledge. There are strong arguments that certain aspects of human and veterinary diagnostics, data collection and analysis need to be combined to create synergies which will improve resource use.

Where resources, skills and institutions could provide a service to both human and animal health delivery and budget constraints limit how much redundancy can be allowed laboratories are an obvious target, and more creative use could be made of epidemiology and socio-economics skills. Better linkages of human and animal health surveillance data may potentially be useful for emerging diseases.

\section{Discussion and conclusions}

The environment that leads to the emergence and reemergence of health problems is dynamic and constantly changing. These changes have led to responses in terms of strengthening disease surveillance, internationally through WHO, OIE, FAO and nationally through multi and bi lateral programmes plus regional agreements. These have generated benefits in terms of:

- Improved understanding of health problem emergence and re-emergence in order to respond in a proportionate and timely manner.

- Generalised systems of health delivery where resources are scarce - very specific situations.

- Combined use of infrastructure and skillsets to improve the use of underutilised resources and create synergies.

The benefits are not constant as the environment is constantly changing. These changing benefits have changing costs that can only be estimated with better monitoring systems of:

- livestock systems

- value chains

- people working within and using these chains.

Yet we have weak systems to monitor the working and behaviour of livestock systems and their associated chains implying that One Health agenda should be expanded to include environmental concerns and human behaviour. Political reality of adopting a One Health agenda also requires thought and needs to be realistic with the development of evidence of added value from One Health approaches through systematic data collection and analysis. The current lack of evidence reflects a lack of funding, collaboration, management and support, and future work needs to pose the following questions:

- How do we improve the monitoring of facilitating environment so we can in real time:

- estimate health problem impact with more accuracy

- estimate the costs (direct costs and institutional costs) of monitoring and control

- estimate benefits from mitigation activities.

We need to search for proportionate and rational responses that involve individuals, communities, Non-Governmental Organisations (NGOs), private and public sectors, and to recognise that no one mechanism will suit all situations - it requires a systems and people centred approach with strong technical leadership.

\section{Acknowledgements}

Madelon Meijer, Oxfam, The Netherlands; Malla Hovi, AHVLA, UK; Wantanee Kalpravidh, David Castellan FAO, Bangkok; Nick Taylor - University of Reading, UK; Liz Redmond - FSA, UK; Katharina Stärk, Dirk Pfeiffer, Javier Guitian - RVC, UK; Mark Rweyemamu and the SACIDS team; Jeff Waage - Leverhulme Centre for Integrative Research on Agriculture and Health, LIDC, UK.

\section{References}

Canadian Public Health Agency, 2009, 'Report of the Expert Consultation on One Health', Winnapeg, March 2009, Canadian Government, Ottawa, Canada.

Chatham House, 2010, 'Shifting from Emergency Response to Prevention of Pandemic Disease Threats at Source', Chatham House, London, UK. 
De Haan, C., Schillhorn van Veen, T., Brandenburg, B., Gauthier, J., Le Gall, F., Mearns, $R$. et al., 2001, 'Livestock development: Implications for rural poverty, the R. et al., 2001, 'Livestock development: Implications for rural poverty,
environment and global food security', The World Bank, Washington DC, USA.

De Haan, C., Steinfeld, H. \& Blackburn, H., 1997, Livestock and the Environment: Finding a Balance, Wrenmedia, Suffolk, UK.

Delgado, C., Rosegrant, M., Steinfeld, H., Ehui, S. \& Courbois, C., 1999, Livestock to 2020. The Next Food Revolution, Food, Agriculture and the Environment Discussion Paper 28. IFPRI, Washington DC, USA.

Food and Agriculture Organisation, 2005, 'Livestock Policies and Poverty Reduction in Africa, Asia and Latin America', Pro-Poor Livestock Policy Initiative Policy Brief, FAO, Rome Italy.

Food and Agriculture Organisation/World Animal Health Organisation/World Health Organisation, 2008, 'Contributing to One World, One Health - A Strategic Framework for Reducing Risks of Infectious Diseases at the Animal-HumanEcosystems Interface', FAO, Rome, Italy.

Gonzalez, A., 2011, email, 29 November, agonzale@jhsph.edu.

Greger, M., 2007, 'The human/animal interface: Emergence and resurgence of zoonotic infectious diseases', Reviews in Microbiology 33, 243-299.

Heffernan, C., 2002, 'Livestock and the poor: issues in poverty focused development' in E. Owen, T. Smith, M.A. Steele, S. Anderson, A.J. Duncan, M. Herrero et al, (eds.), Responding to the livestock revolution: The role of globalisation and implications for poverty alleviation BSAS Publication 33, 229-245.

Jones, K.E., Patel, N.G., Levy, M.A., Storeygard, A., Balk, D., Gittlemman, J.L. et al., 2008, 'Global trends in emerging infectious diseases', Nature (London) 451,990993. http://dx.doi.org/10.1038/nature06536, PMid:18288193

Knobel, D.L., Cleaveland, S., Coleman, P.G., Fevre, E.M., Meltzer, M.I., Miranda, M.E.G. et al., 2005, 'Re-evaluating the burden of rabies in Africa and Asia', Bulletin of the World Health Organization 83, 360-368. PMid:15976877, PMCid:2626230

Maudlin, I., Eisler, M.C. \& Welburn, S.C., 2009, 'Neglected and endemic zoonoses', Philosophical Transactions of the Royal Society of London. Series B, Biological Sciences 364, 2777-2787.

Morton, J., Matthewman, D. \& Barton, D., 1997, Livestock production extension: issues, case studies and policy options. NRI Socio-economic Series 12. Chatham, UK: Natural Resources Institute.
Owen, E., Best, J., Devendra, C., Ku-Vera, J., Mtenga, L., Richards, W. et al., 2005, 'Introduction - the need to change the "mind-set"', in E. Owen, A. Kitalyi, N. Jayasuriya \& T. Smith (eds.), Livestock and Wealth Creation. Improving the husbandry of animals kept by resource-poor people in developing countries,
Nottingham University Press, Nottingham, UK, pp 1-11.

Otte, M.J., Hinrichs, J., Rushton, J., Roland-Holst, D. \& Zilberman, D., 2008, 'Impacts of avian influenza virus on animal production in developing countries', Perspectives in Agriculture, Veterinary Science, Nutrition and Natural Resources, CABI, 3 No. 080.

Roling, N.G. \& Wagemakers, M.A.E. (eds.), 1998, Facilitating sustainable agriculture. Participatory learning and adaptive management in times of environmental uncertainty, Cambridge University Press, Cambridge.

Roth, F., Zinsstag, J., Orkhon, D., Chimed-Ochir, G., Hutton, G., Cosivi, O. et al., 2003, 'Human health benefits from livestock vaccination for brucellosis: case study', Bulletin of the World Health Organization 81, 867-876.

Rushton, J., 2009, The economics of animal health \& production, CAB International, Wallingford (UK) \& Cambridge (USA).

Schelling, E., Bechir, M., Ahmed, M.A., Wyss, K., Randolph, T.F. \& Zinsstag, J., 2007, 'Human and animal vaccination delivery to remote nomadic families, Chad.', Emerging Infectious Diseases 13, 373-379. http://dx.doi.org/10.3201/ eid1303.060391, PMid:17552089, PMCid:2725911

Steinfeld, H., Gerber, P., Wassenaar, T., Castel, V., Rosales, M. \& De Haan, C., 2006, Livestock's Long Shadow Environmental Issues and Options, FAO, Rome, Italy.

Van Veldhuizen, L., Waters-Bayer, A., Ramirez, R., Johnson, D. \& Thompson, J., 1997, Farmers' research in practice - lessons from the field, Intermediate Technology Publications, London.

Woolhouse, M.E., 2008, 'Epidemiology: emerging diseases go global', Nature (London) 451, 898-899. http://dx.doi.org/10.1038/451898a, PMid:18288175

Woolhouse, M.E.J. \& Gowtage-Sequeria, S., 2005, 'Host range and emerging and reemerging pathogens', Emerging Infectious Diseases 11, 1842-1847. http:// dx.doi.org/10.3201/eid1112.050997, PMid:16485468, PMCid:3367654

World Bank, 2010, People, Pathogens and Our Planet. Volume 1: Towards a One Health Approach for Controlling Zoonotic Diseases, The World Bank, Washington, USA.

Zinsstag, J., Schelling, E., Roth, F., Bonfoh, B., Savigny, D.D. \& Tanner, M., 2007, Infectious Diseases, 13,527-531. http://dx.doi.org/10.3201/eid1304.060381, PMid:17553265, PMCid:2725951 